\title{
RENEWAL PARADIGM OF THE LDII COMMUNITY IN KEDIRI
}

\author{
Hilmi Muhammadiyah \\ STAI Nahdlatul Ulama Jakarta, Indonesia \\ E-mail: hilmi_elsas@yahoo.com
}

\begin{abstract}
This article attempts to explore the dynamics of the Lembaga Dakwah Islam Indonesia (LDII) or Indonesian Islamic Da'wah Institution community in Kediri of East Java, Indonesia in maintaining its existence, transforming and seeing the processes, patterns and strategies that developed by the LDII. The article elaborates how social actors of the LDII carry out social practices continuously, so that LDII can continue to survive, develop, and reform the doctrine and religious identity paradigm and its organizational identity thus being accepted by people in the region. The role of the actors as the agent in changing the character of the movement is discussed in this work. They have made strategies including building closeness to the authorities, building attitudes of openness, changing the image of the organization, strengthening identity, establishing dialogue and public cooperation with the Indonesian Ulema Council (MUI - Majelis Ulama Indonesia) that positioning LDII as a heretical and splinter organization, and establishing cooperation with Religious Community Organizations (Ormas) that are considered mainstream, such as NU (Nahdatul Ulama) and Muhammadiyah. This work attempts to provide materials and considerations in dealing with the issue raising between the flow of splinters and established groups.
\end{abstract}

Keywords: cooperation, LDII, renewal, paradigm, Kediri

\section{INTRODUCTION}

Community of Indonesian Islamic Da'wah Institutions (LDII) is originally known as Jamaah Islam. LDII or Islamic Jamaah was founded around the 1970s. The people of Kediri are publicly understood to adhere to the ideology of the Jamaah Islam. The ideology of the LDII has been able to influence the daily activities of its members marking them to have a different character from most Muslims in the region. Unlike the followers of mainstream Islam, LDII/ Islamic citizens Jamaah often get discriminatory treatment, both from adherents of mainstream Islam and from the government. This was triggered by religious behavior practiced by Jamaah Islamic groups. The state 
(government) has a strong intervention to determine which religion is worthy of being embraced by its citizens. Because that is not surprising if the type of freedom practiced in Indonesia as limited pluralism (limited pluralism) (Howell, 2005). Not only determining a number of official religions that are recognized for being embraced by their citizens, more than that, the state also regulates that the flow and community does not deviate from the mainstream of the recognized religion.

The LDII controversy among other groups is the use of the concept of congregation. The concept stipulates LDII to choose an exclusive path, even denying the Islam of other groups, for example the command of prayer must be led by people who only come from their group. Among them also developed the assumption that people who were not his group were considered unclean, people who entered the mosque, the mosque had to throw up or dipel the floor. Accompanying the congregation's doctrine includes the concept of Bai'at and Imamat, namely the provision of the system of Bai'at by a leader can become a member. This gift is also a way or entrance to enter heaven. The doctrine is well known in Jamaah Islam, for example: "Whoever does not follow the pledge of loyalty to the imam , they have not become Muslims; other than that, a legitimate congregation that is recognized by one, namely a congregation that has pledged allegiance to their imam who holds the title of believer in the faith. "

The next controversial doctrine is the manqul doctrine, which is the transmission of knowledge originating from the Qur'an and the new Sunnah which is considered true or has a background or out of the mouth of the imam or amir, namely Nur Hasan al-Ubaidah's decision. Asam, the traditions included are history or excerpts from Nur Hasan al-Ubaidah. Other doctrines are the teachings of Taqiyyah, Fathonah, Bithonah, "Budi Luhur Luhuring Budi Kerana Allah". Taqiyyah is actually similar to the Shiite concept of silence. In the initial phase of the establishment of the LDII community in Kediri, Nur Hasan al-Ubaidah faced the Nahdlatul Ulama community who had religious rituals that were tradition. The community at that time had been formed as Muslims who did not feel deprived of their cultural roots. The community groups with Javanese Islam (Woodward, 2006). The process of Islamization in Java has not been completed due to two things (Azra, 2000). First, Java has the most established Indian court tradition compared to other countries in the archipelago that accept Islam. Second, taking away from being involved in the international Islamic network in the 19th century in Java is more clearly than other regions in Indonesia.

The word Darul Hadith, which was inaugurated by Nur Hasan al-Ubaidah, is a 
form of reform of traditional Islam that developed in his area, Kediri, East Java. Borrowing Weber's theory in Giddens (1986: 154), Nur Hasan al-Ubaidah's rift with traditional Islam produced a calendar of traditions in general, and specifically extinguished religious institutions in their old-fashioned form (Giddens, 1984, 1990, 2016)its deep undercutting of traditional habits and customs, and its global impact. It also radicallly alters the general nature of daily life and the most personal aspects of human activity. In fact, one of the most distinctive features of modernity is the increasing interconnection between globalizing influences and personal dispositions. The author analyzes the nature of this interconnection and provides a conceptual vocabulary for it, in the process providing a major rethinking of the nature of modernity and a reworking of basic premises of sociological analysis.Building on the ideas set out in the authors The Consequences of Modernity, this book focuses on the self and the emergence of new mechanisms of self-identity that are shaped byyet also shapethe institutions of modernity. The author argues that the self is not a passive entity, determined by external influences. Rather, in forging their self-identities, no matter how local their contexts of action, individuals contribute to and directly promote social influences that are global in their consequences and implications. The author sketches the contours of the he calls high modernitythe world of our dayand considers its ramifications for the self and self-identity. In this context, he analyzes the meaning to the self of such concepts as trust, fate, risk, and security and goes on the examine the sequestration of experience, the process by which high modernity separates day-to-day social life from a variety of experiences and broad issues of morality. The author demonstrates how personal meaninglessnessthe feeling that life has nothing worthwhile to offerbecomes a fundamental psychic problem in circumstances of high modernity. The book concludes with a discussion of life politics, a politics of selfactualization operating on both the individual and collective levels.",')author": [ [ "droppingparticle":",",family":"Giddens","given":"Anthony","non-droppingparticle":"'”',parse-names":false,"suffix":"'’\}],"container-title":"Social Theory Re-Wired: New Connections to Classical and Contemporary Perspectives: Second Edition'”'id”:"'ITEM-1'”'issued”:\{“date-parts":[[“2016”]]\},"title":”M odernity and self-identity"',type":"chapter"],"uris":["http://www.mendeley. com/documents/?uuid=a31fdcb7-2f06-41de-9641-bfa5dd9e98dc",'http:// www.mendeley.com/documents/?uuid=23d3bbc2-8cc4-47ce-99d60 ebd8be4b015”]\},\{“id”:"ITEM-2","itemData":\{“DOI”:"10.1007/ BF01173303"," ISBN":"978-0-520-05292-5","ISSN":"0147-5916, 1573-2819'"'PMID":"2418146"','abstract":"Anthony Giddens has been in the forefront of developments in social theory for the past decade. In I"The 
Constitution of Societyl" he outlines the distinctive position he has evolved during that period and offers a full statement of a major new perspective in social thought, a synthesis and elaboration of ideas touched on in previous works but described here for the first time in an integrated and comprehensive form. A particular feature is Giddens's concern to connect abstract problems of theory to an interpretation of the nature of empirical method in the social sciences. In presenting his own ideas, Giddens mounts a critical attack on some of the more orthodox sociological views. I"The Constitution of Societyl" is an invaluable reference book for all those concerned with the basic issues in contemporary social theory.",'”uthor":[[“dropping-particle" :"','”family":"Giddens"',given":"Anthony","non-dropping-particle":"',"parsenames":false,"suffix":"''\}],"container-title":"The constitution of society: Outline of the theory of structuration'”',id":"ITEM-2"',issued":\{“dateparts":[[“1984"]]\},"title":” The constitution of society: Outline of the theory of structuration"',type":"chapter"],"uris":["http://www.mendeley.com/ documents/?uuid=c90c3e3c-b2ad-40de-82b7-9e87924d420c"," http:// www.mendeley.com/documents/? uuid=feb3ab9b-cfdb-4556-a011ab84b3f75ccl”]\},\{“id”:”ITEM-3"”'itemData”:\{“DOI”:"10.2307/591454"”ISBN ":"0745609236"',ISSN":"15562646"',PMID":"3401163'”'abstract":"Inthismajor theoretical statement, the author offers a new and provocative interpretation of institutional transformations associated with modernity. What is modernity? The author suggests, I"As a first approximation, let us simply say the following: 'modernity' refers to modes of social life or organization which emerged in Europe from about the seventeenth century onwards and which subsequently became more or less worldwide in their influence.l" We do not as yet, the author argues, live in a post-modern world. The distinctive characteristics of our major social institutions in the closing years of the twentieth century suggest that, rather than entering into a period of post-modernity, we are moving into a period of ।"high modernityl" in which the consequences of modernity are becoming more radicalized and universalized than before. A post-modern social universe may eventually come into being, but this as yet lies on the other side of the forms of social and cultural organization that currently dominate world history. In developing a fresh characterization of the nature of modernity, the author concentrates on the themes of security versus danger and o trust versus risk. Modernity is a double-edged phenomenon. The development of modern social institutions has created vastly greater opportunities for human beings to enjoy a secure and rewarding existence than in any type of pre-modern system. But modernity also has a somber side that has become very important in the present century, such as the frequently degrading nature of modern industrial work, the growth of totalitarianism, 
the threat of environmental destruction, and the alarming development of military power and weaponry. The book builds upon the author's previous theoretical writings and will be of great interest to those who have followed his work through the years. However, this book covers issues the author has not previously analyzed and extends the scope of his work into areas of pressing

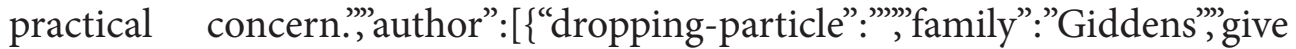
n":"Anthony"',non-dropping-particle":"',"parse-names":false,"suffix":"'’\}],"co-

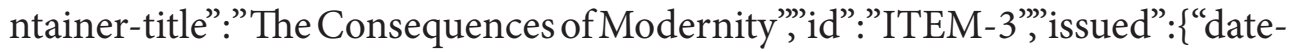
parts":[[“1990"]]\},"title":"Introduction","type":"chapter”],"uris":[“http:// www.mendeley.com/documents/? uuid $=55$ fecd06-735b-4760-9e83f2cdd2f4d482"',http://www.mendeley.com/documents/?uuid=a2c7938d65a8-4068-a39b-72138ba7e48c"]\}],"mendeley":\{“formattedCitation":"(Gidde ns, 1984, 1990, 2016. Nur Hasan al-Ubaidah had indeed escaped his followers from the control of the Islamic tradition that had developed at that time. Nur Hasan al-Ubaidah also introduced the concept of Darul Hadith strictly so that her followers did not have time to relax and have fun with their old traditions. The LDII community also transforms from a closed community to an open one. Even though it is more open now, the LDII community is able to maintain its religious doctrine and identity and organizational identity. LDII's convincing identity and symbol to exist with its distinctiveness as a form of expression of belief that has encouraged the understanding of society and the state to respect different beliefs, and support a calm and friendly life in a pluralistic society. The fundamental change made by LDII is that they began to open up to other communities and groups.

The birth of the MUI went hand in hand with the surrender of moral authority from the government to the MUI is indirectly benefiting LDII. MUI products have compressive power and save force. This condition was used by LDII, so they preferred to approach the MUI rather than approach religious organizations such as Nahdlatul Ulama (NU) and Muhammadiyah. However, lately the LDII community also approached religious organizations such as NU and Muhammadiyah. In addition, according to Azis (one of the administrators of the LDII Burengan Islamic Boarding School), LDII has now undergone changes, both from the pattern of internalization of the culture instilled and from social interaction with other groups. This work reveals the paradigm of a typical religious community in carrying out strategies to maintain its existence so that it can survive in facing various problems of socio-religious discrimination. This research is expected to be a reference for leaders or anyone in determining attitudes or policies towards socio-religious issues. 


\section{RELIGION, AGENCY, REGIONALIZATION, AND GLOBALIZATION}

The study of religion has been developing for a long time. Some theories about religion can also be learned. Among them is what was done by Durkheim (Giddens, 1984) who states that the idea of society is actually the spirit of religion. This opinion was written in a book entitled The Elementary Forms of the Religious Life, which was published in 1915. Durkheim's interpretation gave meaning that religion basically was crucial for the presence of social dynamics of a society. Religion plays a very important, even decisive role in building the social world. Religion is not only a means of control for all the actions of its followers, but also becomes a color giver for the social dynamics of society. The more religion is believed by the true beliefs of the adherents, eating will make the "color of religion" more thick on the character of the person concerned. So, all human actions are strongly influenced by religion. The other influential scholar within the studies of religion is Radcliffe-Brown. In understanding religion he followed Durkheim by arguing that there was no point in seeking the epistemological status of religion as a false illusory belief. Similarly, there is no point in examining the origin of religion. On the contrary, we must view religious belief and worship as part of a complex system by which humans begin to live together in a regular form. According to him we must look at the social function of religion, namely the contribution he gives in shaping and maintaining social order - we must focus more on rituals than beliefs (Morris, 2003).

In a different perspective, religious teachings are a spirit for humans in shaping civilization (Anonymous, 1986). In this context, modern theory clearly looks at the existence of religion as a functional value. Functional value is a value that can build people towards future progress and order. It is this life's order that is the main target or target of the human soul as a creature with two dimensions - the dimensions of the body and soul. Religion provides answers to statements about the origin of the universe and questions about human life after death (Giddens, 1984, 1990, 2016)its deep undercutting of traditional habits and customs, and its global impact. It also radicallly alters the general nature of daily life and the most personal aspects of human activity. In fact, one of the most distinctive features of modernity is the increasing interconnection between globalizing influences and personal dispositions. The author analyzes the nature of this interconnection and provides a conceptual vocabulary for it, in the process providing a major rethinking of the nature of modernity and a reworking of basic premises of sociological analysis.Building on the ideas set out in the authors The Consequences of Modernity, this book focuses on the self and the emergence of new mechanisms of self-identity that are shaped byyet also shapethe institutions of modernity. The author argues that the self 
is not a passive entity, determined by external influences. Rather, in forging their self-identities, no matter how local their contexts of action, individuals contribute to and directly promote social influences that are global in their consequences and implications. The author sketches the contours of the he calls high modernitythe world of our dayand considers its ramifications for the self and self-identity. In this context, he analyzes the meaning to the self of such concepts as trust, fate, risk, and security and goes on the examine the sequestration of experience, the process by which high modernity separates day-to-day social life from a variety of experiences and broad issues of morality. The author demonstrates how personal meaninglessnessthe feeling that life has nothing worthwhile to offerbecomes a fundamental psychic problem in circumstances of high modernity. The book concludes with a discussion of life politics, a politics of selfactualization operating on both the individual and collective levels.,'”author":[\{“dropping-particle":"',',family":"Giddens','giv en":"Anthony'"',non-dropping-particle":"',"'parse-names":false,"suffix":"'’\}],"container-title":"Social Theory Re-Wired: New Connections to Classical and Contemporary Perspectives: Second Edition"','id":'ITEM1','issued”:\{“date-parts":[[“2016”]]\},"title”:"Modernity and self-identity'”'type ":"chapter"],"uris":[“http://www.mendeley.com/documents/?uuid=23d3bbc28cc4-47 ce-99d6-0ebd 8be 4b015"," http://www.mendeley.com/ documents/?uuid=a31fdcb7-2f06-41de-9641-bfa5dd9e98dc”]\}, ‘“id”."ITEM2"'”itemData":\{“DOI”:"10.1007/BF01173303",'ISBN":"978-0-520-052925'”'ISSN":"0147-5916, 1573-2819','PMID":"2418146','abstract":"Anthony Giddens has been in the forefront of developments in social theory for the past decade. In I"The Constitution of Societyl" he outlines the distinctive position he has evolved during that period and offers a full statement of a major new perspective in social thought, a synthesis and elaboration of ideas touched on in previous works but described here for the first time in an integrated and comprehensive form. A particular feature is Giddens's concern to connect abstract problems of theory to an interpretation of the nature of empirical method in the social sciences. In presenting his own ideas, Giddens mounts a critical attack on some of the more orthodox sociological views. I"The Constitution of Societyl" is an invaluable reference book for all those concerned with the basic issues in contemporary social theory."') author":[\{“dropping-part

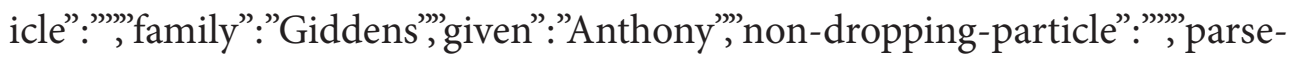
names":false,"suffix":"'\}],"container-title":"The constitution of society: Outline of the theory of structuration"','id":'ITEM-2",'issued":\{“dateparts":[[“1984"]]\},"title":"The constitution of society: Outline of the theory of structuration"',type":"chapter"],"uris":["http://www.mendeley. com/documents/?uuid=feb3ab9b-cfdb-4556-a011-ab84b3f75cc1",',http:// 
www.mendeley.com/documents/? uuid $=c 90 c 3 e 3 c-b 2 a d-40 d e-82 b 7-$ 9e87924d420c"',http://www.mendeley.com/documents/?uuid=9cae99ad56f9-4f33-8c3b-d60f386c9fa 8"]\}, \{“id":"ITEM-3","itemData":\{“D OI":"10.2307/591454","ISBN":"0745609236","ISSN":"15562646","PMID":"3401163'"'abstract":"In this major theoretical statement, the author offers a new and provocative interpretation of institutional transformations associated with modernity. What is modernity? The author suggests, I"As a first approximation, let us simply say the following: 'modernity' refers to modes of social life or organization which emerged in Europe from about the seventeenth century onwards and which subsequently became more or less worldwide in their influence.l" We do not as yet, the author argues, live in a post-modern world. The distinctive characteristics of our major social institutions in the closing years of the twentieth century suggest that, rather than entering into a period of post-modernity, we are moving into a period of \"high modernityl" in which the consequences of modernity are becoming more radicalized and universalized than before. A post-modern social universe may eventually come into being, but this as yet lies on the other side of the forms of social and cultural organization that currently dominate world history. In developing a fresh characterization of the nature of modernity, the author concentrates on the themes of security versus danger and o trust versus risk. Modernity is a double-edged phenomenon. The development of modern social institutions has created vastly greater opportunities for human beings to enjoy a secure and rewarding existence than in any type of pre-modern system. But modernity also has a somber side that has become very important in the present century, such as the frequently degrading nature of modern industrial work, the growth of totalitarianism, the threat of environmental destruction, and the alarming development of military power and weaponry. The book builds upon the author's previous theoretical writings and will be of great interest to those who have followed his work through the years. However, this book covers issues the author has not previously analyzed and extends the scope of his work into areas of pressing practical concern.,'”author”: [ ‘“droppingparticle":"',"family":"Giddens","given":"Anthony","non-droppingparticle":"',"parse-names":false,"suffix":"”\}],"container-title":"The Consequences of Modernity"',id":"'ITEM-3"', issued":\{“date-parts":[[“199 0"]]\},"title":"Introduction'”,type”:"chapter"],"uris":[“http://www.mendeley. com/documents/?uuid=a2c7938d-65a8-4068-a39b-72138ba7e48c',"'http:// www.mendeley.com/documents $/$ ? uuid $=55$ fecd06-735b-4760-9e83f2cdd2f4d482'"'http://www.mendeley.com/documents/?uuid=3ce3a3f1-aa2c45ca-9781-66cfe0c7400b"]\}],"mendeley":\{“formattedCitation":"(Giddens, $1984,1990,2016$. This indicates that the explanation and meaning inherent in 
religion transcends the limitations of human mind and logic. For the Giddens, there are always "objects" or supernatural beings whose existence is beyond the reach of the human senses and brings a feeling of awe. According to the Giddens, the creature could be a divine power or personalization of the gods. In Islam the power manifests itself in the existence of Allah. In Hinduism, the supernatural creatures that are being worshiped are single. They appear in many manifestations, such as deities, ancestral spirits, and others. However, Giddens underlined that religion establishes moral guidelines that control and limit the behavior of its adherents.

LDII's existence can be read from the perspective of the structuration theory developed by Giddens (1984). The core of the structuration theory is seeing agents and structures in relations of duality. However, agents are involved in structures and structures involving agents. According to him, all social actions require structure and the entire structure requires social action. The Giddens refused to see the structure merely as a force against agents (such as Durkheim). He looked more at the structure both as an enforcer and provider of opportunities. Structure not only functions to inhibit and determine forms of behavior, but also provides the ability for behavior. In other words, the structure provides opportunities and restrictions at once. Furthermore, Giddens placed humans in a very significant position which he called "agency". That is, with this position humans can reproduce and have abilities, and understand the intent and purpose of all the actions they take. Agency is anything that an actor does in a particular situation that has certain consequences, even though the consequences do not have to be as intended by the perpetrator himself. The actions of every human being, therefore, must be seen as one duree or a series of actions that are stretched in a long dimension of space and time which have certain consequences.

Another structuring theory is regionalization. The character of the interaction location can be explored in relation to the different locations through which daily activities of individuals are coordinated. Location is not just a place, but a setting or setting of regionalization interactions. This location must be understood not only as localization in space, but also refers to the determination of space-time zones in relation to routine social practices. For Giddens, to live in today's modern society we must shape and reshape ourselves to be able to deal with changes in our environment. Giddens views that globalization is a restructuring of the ways people live their lives in a very deep way. But he also acknowledged that globalization was a two-way process, with America and the West being the most affected regions. Globalization also weakens local culture and revives it. Giddens said that globalization "sneaked 
aside" produced new areas that might cross nations. He gave an example of the area around Barcelona in Northern Spain whose area extends into France. The main clash and challenge that occurs at the global level today is between fundamentalism and cosmopolitanism. Giddens (1990) saw the emergence of a "global cosmopolitan society". However, even the main forces that oppose it traditionalism are products of globalization. Furthermore, fundamentalism uses global forces, such as mass media, to expand its objectives. Fundamentalism can take various forms including religion, ethnicity, nationalism, and politics.

This work is based on the studies of the people who have knowledge and information about the history of LDII that was established as an Islamic Jamaah and immediately felt the condition of Islamic congregation and the next generation that had joined since it changed to LDII. In-depth interviews were also conducted with religious, community and government leaders. The observation is the basis of the study of cultural anthropology carried out by researchers, considering that this method is a pattern of data collection which is the estuary of ethnographic processes. In the context of the involved observation, researchers are at the level of complete involvement with LDII. The observations done by the researcher do manifest in social and emotional relationships. Actors are people who become objects of observation in a natural setting (Spradley, 1979). A person must blend in daily activities and experiences more closely, both physical closeness and social closeness, to record the daily activities of the community being studied (Emerson, 1995). Therefore, researchers entered the center of the LDII community's life to get to know them closely, both those that took place in mosques, study rooms, and recitations and meetings, to absorb what they experienced and understand their activities. The immersion of researchers into ways of life, speech, behavior, and thinking of the society they study is highly recommended to obtain data as complete as possible (Fetterman, 2010).

\section{LDII WITHIN BURENGAN ISLAMIC BOARDING SCHOOL AND NUR HASAN AL-UBAIDAH'S BOARDING SCHOOL}

Burengan Islamic Boarding School is located at Jalan H. O. S. Cokroaminoto 195, Kediri City, precisely in Banjaran Village with an area of +126 hectares (Anonymous, 1999). Currently Burengan is home to around 3,000 students. Burengan cannot be separated from the figure of a kiai named KH Nur Hasan al-Ubaidah, the main character and founder of the pesantren around 1952. According to Kuncoro, one of the informants in the fields and a LDII senior activist, former head of the LDII Burengan Islamic Boarding School, and former village head, the full names of important figure in LDII is Nur Hasan 
al-Ubaidah Lubis bin Abdul bin Thahir bin Ershad, born in Bangi Village, Purwosari District, Kediri Regency, East Java, in 1915. In his childhood, Nur Hasan al-Ubaidah received direct religious guidance from his own father, $\mathrm{H}$. Abdul Aziz bin Tahir bin H. Isyad. After growing up, Nur Hasan al-Ubaidah began studying from one hut to another cottage, such as Pedes, Samelo, Perak Jombang, Balong Jeruk, even once boarding at Lirboyo, the largest pesantren which became the base and was known as "NU Pesantren". As told by K. $\mathrm{H}$. Idris Marzuki when interviewed at the Lirboyo Kediri Islamic Boarding School, "Nur Hasan al-Ubaidah once boarded here at Lirboyo, but not for long. His son was quite intelligent and at that time like most santri who were here, followed the study diligently. I do not understand, suddenly he became an Islamic leader of the Jamaah, where did he get that understanding? Even though in this pesantren it is not like that understanding. "

In the beginning, the target of Nur Hasan al-Ubaidah's da'wah was his own family, then spread widely to the community. The precious moment of the da'wah process began with the allegiance of loyalty to Nur Hasan al-Ubaidah as a leader by his followers which occurred in 1941. When getting more followers of his recitation, a community was formed and called the Jamaah of the Quran and Hadith. Since then, there has been a legitimate community with legitimate leaders. As for the start of the movement, Nur Hasan al-Ubaidah community has made recruitment of members voluntarily. His teachings affirm the characteristics of the group as a religious group that is different from other Islamic groups. The presence of Nur Hasan al-Ubaidah empirically is a phenomenon of a figure that is able to construct culture. Nur Hasan alUbaidah can educate someone who cannot read at first to be able to recite. The method is to read first, while the tajwid is learned after being able to read.

\section{THE DOCTRINE TO RETURN TO AL-QUR'AN \& HADITH}

Based on interviews with Kuncoro (LDII activist) and "lecturers" at the LDII Burengan Islamic Boarding School, Nur Hasan al-Ubaidah introduced the points of doctrine back to the Qur'an and hadith. Therefore, the activities of santri cannot be separated from studying the Qur'an and hadith. Reading the Qur'an is done with the target of completing the recitation of the Qur'an in a certain time, then in time the santri faces the teacher who has been assigned to check the reading and memorizing abilities at the level of each santri. The themes for holding fast to the Qur'an and hadith are central themes in LDII recitations.

Some of the doctrines taught by Nur Hasan al-Ubaidah include, first, the Manqul doctrine (transmission of science), that the followers of Islam 
Jamaah must have scientific transmission from their leaders. Second, the Baiat doctrine, which is the promise of loyalty to God to be consistent with the religion witnessed to Muhammad SAW or the leader (in this case is Nur Hasan al-Ubaidah). Loyalty is the command of God and the Apostle. Third, the doctrine of Jama'ah (community), Nur Hasan al-Ubaidah emphasized that Muslims must have community in order to survive. Communities are not limited to carrying out prayers, but also in other activities. Fourth, the doctrine of Imamah (leader). His teaching recognizes someone who is appointed as a single leader with a system of loyalty. The leader has the authority to determine everything, both the issue of religious rituals and profane activities. Fifth, the Doctrine of Amal Saleh, 9 (nine) virtuous deeds which must be adhered by LDII worshipers, namely to increase introspection and ask forgiveness to God; increase financial sacrifice for good; increase communication; happy to respect guests; trying to be honest and trustworthy; increase submission to God; always prejudiced good to God; order night rituals; and contemplate in one third of the night.

\section{LDII: FROM KEDIRI TO JAKARTA}

As a religious group, this school initially named itself as Darul Hadith and centered in East Java. Because it was considered disturbing to the community, East Java's Trustees of Public Trust (PAKEM) banned the teachings, so the Decree of the East Java Regional Military Commander VIII was issued signed by Mayjen Jasin in 1967 concerning the prohibition of the teachings of Darul Hadith. The ban was responded to by changing the name of Pondok Darul Hadits to the Jamaah Islamic Education Foundation. In various regions, various names have emerged with the same content of teachings. Nur Hasan al-Ubaidah's followers in Jakarta named his group with the National Education Board Foundation (Yappenas); in the Tanjung Karang Jamaah Darul Hadits; in Bogor Darul Hadith Movement; in Yogyakarta and the Lamlus Sunah Wal Jamaah Educational Institution; in Gunung Kidul Pure Islamic Congregation; and in Bantul Manqul Islamic Jamaat. The vital role of Nur Hasyim was able to elevate the image of the Jamaah Islamic suburban movement into a middleclass movement that was equal to other groups, Thohir Nur Hasyim, the Jamaah Islamic reformist group (Thohir, 2009). The significant contribution of Nur Hasyim was also in the form of two books on the subject of Jama'ah Islamic teachings which now become their main points. Seven Facts as the Shahah of Jamaah Leadership in Indonesia and Delaying the Claim of Harming Themselves Nur Hasyim was also in the Islamic community of the Jamaah as the second person of the Jamaah Islamic teachers. 
The efforts of Nur Hasyim to rationalize the Islamic doctrine of the Jamaah in fact cannot avoid this group from the public spotlight. One of the implications of public attention is the colorful names of Islamic group followers of Nur Hasan al-Ubaidah. Nur Hasan al-Ubaidah's followers make movement with various names in the area lasted until the publication of a ban from the government. Islamic Jamaah/ Darul Hadith was banned by the Attorney General of the Republic of Indonesia in 1971 (Anonymous, 1971), because it was seen as a deviant group of mainstream Islamic groups. Some of the religious doctrines of Nur Hasan al-Ubaidah's followers and practices are considered controversial. The prohibition from the government caused Nur Hasan al-Ubaidah's followers to experience difficulties in carrying out their activities. Several steps of approach and cooperation to all religious groups are increasingly increasingly fierce, including approaches to authorities at all levels. Some of Nur Hasan al-Ubaidah's students in East Java, including Nur Hasyim, R. Eddi Masiadi, Bahroni Hartanto, Soetojowirjoatmodjo, and Wijono, initiated the idea of forming the LEMKARI organization as an effort to encourage recitation activities more openly to the community. They then went to the notary who lived in Surabaya, Mudiomo, to make and sign the LEMKARI Establishment Deed on January 3, 1972. The colorful names of these institutions in various conquered areas became the LEMKARI Foundation based on a decision taken at the LDII Islamic Boarding School alumni meeting date 9-10 February 1975. The organizational structure was perfected a year later through working meetings in Kediri on 2-3 February 1976.

The existence of LEMKARI gave rise to a new strategy by approaching the state- in this case the ruler who was then dominated by Golkar - by declaring itself to be in line with Golkar. With the new name LEMKARI and taking refuge under Golkar, this group was able to build a broad network and be free to all corners of the archipelago. However, the challenge that must be faced is not over. LEMKARI was again confronted with a freeze by the Governor of East Java, Soelarso, with Decree No. 618 of 1988. The freeze came into effect on December 25, 1988 at the insistence of the East Java MUI because LEMKARI was considered disturbing the community. The change of name of this movement occurred again in 1990, in the LEMKARI VI Grand Consultation forum in Jakarta which decided the name LEMKARI to change to LDII. LDII developed an effort nalemy "Success Chess". The first success chess is trying to improve organizational performance by organizing and improving the existence of LDII as a community organization that focuses on religious activities and community education. The second success chess is to increase human resources by establishing training centers, such as craft workshops and building skills as well as English and computer courses. The third success 
chess is empowering the potential of the people. Success chess is directed at gaining happiness in life based on harmony in the world and the hereafter, namely by mobilizing joint business groups in the fields of fulfillment of basic needs, workshops, and contracting companies.

The change of name to LDII is not in vain. Islamic groups that often voiced opposition began to subside. LDII is also getting closer to the government. Another development is the spread of LDII which has expanded to have representation in almost all provinces in Indonesia. LDII also established intensive communication with other religious organizations, such as NU, MUI, Muhammadiyah, Persis, and others. LDII carried out structural consolidation along with the process of ideological renewal. In this context, LDII positioned the Burengan Islamic Boarding School as the ideological basis and center for the organization's ideological cadre nursery. Some LDII activities were even able to show their existence in the community. LDII's organizational network is growing and economically stronger. One of the administrators explained the pattern of relations between science and economics below.

"Science and economic activity go hand in hand because the economy is the source. With knowledge will bring economy, whereas without science the economy will not emerge. LDII knows the doctrine: if you look for the hereafter it will get the world. To the market for buying cattle, the bridle will also be able to win. But if you buy a bridle, you can't get a cow. Fundraising in LDII is done by not smoking. One third of the cigarette is for good deeds, one third for families, and one third for savings. The effect will be healthy and God willing, it will collect fantastic money for the people."

According to H. Usman, LDII membership has two types: the permanent and the non-permanent. Permanent members include administrators and teachers, while non-permanent members include pengajian worshipers. The LDII membership system is open; anyone may join.

\section{RENEWAL PARADIGM}

Some people understand the LDII as an integral part of its historical roots, namely Jamaah Islam. Therefore, LDII also carries out certain strategies to maintain its existence. The first strategy was to change the outer skin of organizational identity by making a change of name and reformulation of the movement. This strategy was chosen given that state protection at that time could also be influenced by other dominant group battles which encouraged the government to judge LDII. The second strategy is to reformulate ideology, 
namely the ideological paradigm shift and changes in religious behavior from the original to become more inclusive. When the first time went to Kediri, the researcher was accompanied by one of the LDII activists and LDII central management. At Juanda Airport, a number of LDII East Java officials have been waiting and we were warmly welcomed. After getting acquainted we were invited to the car that had been provided. But before leaving Surabaya for Kediri we were invited to lunch at one of the restaurants in the Juanda area. Later, researchers learned that such a thing was LDII's fixed procedure in receiving guests or anyone who would come to LDII. Furthermore, this turned out to be part of the implementation of LDII teachings to respect guests. A LDII activist explained:

"LDII has the task of straightening out Jamaah Islam. So how can we be the successors of the Jamaat Islam even though we were given the task of straightening out Jamaah Islam? This is what non-LDII friends need to understand. Some time ago a new identity was attached to us as a new paradigm group. We actually do not fit the term new paradigm because if there is a new paradigm, we have an old paradigm. Even though we are LDII, it is not related to any organization or group before."

LDII changes to be an open organization and community together with fundamental changes in culture that occur in it. From a traditional religious group that has a cultural center in the countryside, LDII gradually becomes a religious group that is not only a splinter, but transforms into a religious group that has followers of the upper middle class even though its centers in the villages still survive. For people outside LDII, it is hard to get them to talk. But now there is openness. They are easily invited to dialogue, no longer close exclusive.

Indonesian traditional society basically has dynamic characteristics (Dove, 1988). Traditional societies always experience continuous social change according to internal challenges and external forces that influence it. The change in the paradigm of religious behavior from close to open is an inevitable change, because the LDII community interacts with the outside world in the era of globalization. According to Sahlins (1981) almost certainly there is not one society in the world that does not interact with the culture outside themselves. Therefore, the LDII community has undergone a change from only the religious community to a religious organization that applies modern organizational principles and complies with the prevailing laws and regulations. Changes that occur are caused by increasingly heterogeneous LDII citizens, both in terms of educational and professional backgrounds, 
which provide a distinctive nuance in the change of view. The occurrence of marriage between LDII residents and non-LDII citizens is also unavoidable. For example, Mr. H. Usman, Chair of the LDII Kediri Branch, who is married to a member of Fatayat (NU youth organization). Although in the early days of the Islamic establishment of the Jamaah, Nur Hasan al-Ubaidah did not allow marriage outside the Islamic community of the Jamaah.

Internal actors play an important role in internal changes in the LDII Kediri environment. The first is Sunarto, which is intensely in the midst of the LDII Kediri community. Sunarto was born on October 28, 1952. Sunarto said, "At first I did not understand, but after learning gradually (I understand). In the past, only learned about the procedures for prayer, then the sunnah prayers, the arguments of discipline, and obedience. Now the teaching has developed. "The methods and teachings conveyed through the recitations carried out by LDII were deemed suitable by Sunarto, so that through his recitation he succeeded in studying and deepening the Qur'an and Hadith. According to him the teaching methods and subject matter in the LDII study have become a tradition that has lasted until now. The role of Sunarto in the LDII community is to provide understanding to the public about the importance of management in managing organizations or institutions. He also conducted intensive communication with various levels of society to build a positive image of LDII which had been considered tilted by the community.

The second is H. Usman, who currently serves as Chair of the LDII of Kediri Regency. He represented LDII at the Kediri Regency Indonesian Ulema Council. The author witnessed several roles of H. Usman in establishing communication with community elements such as the police and the army. He pioneered the construction of a tennis court that was specifically owned by LDII and always shared to people from other agencies three times a week for having exercise together. They initiated tennis championships conducted in an atmosphere that is harmonious, cheerful and full of family spirit among players from different agencies. The third figure is Kuncoro. For Kuncoro, the religious movement against the government was never lasting. According to him, basically Pancasila has provided an opportunity for the community to embrace the religion they believe in, so that it is suitable for a diverse Indonesian society. The fourth update figure is H. M. Bayu Afiudin, S.E. This figure holds the principle that Islam is a religion that is a blessing for all nature. He has developed 4 (four) things in the development of LDII, namely advancing the economy of citizens by empowering joint ventures (UB), developing concern for the social environment, developing awareness of the environment, and revitalizing political power. 


\section{CONCLUSION}

It is the fact that before the new era of the renewal organization, the LDII people are not easy to give answers to questions before getting permission from the emir. Even when a community member speaks they will be accompanied by several people; they do not dare to be alone in having discussions with strangers. The development has been very surprising that the LDII has grown to a more open community. The members have been familiar to ask questions and convey their thoughts and proposals. When asked for an explanation, they can provide a complete and good explanation. But when there is a meeting of figures, the instructive tendency to the congregation is still visible. Even though the LDII members are the latest, they appear to be afraid to be unwilling to submit obediently. These are remnants of past habits that are still visible and have not disappeared until now. The four LDII activists have renewed the changes in the socio-cultural paradigm that is usually the other group, so that until now LDII still exists in the community. LDII with its new face at this time also begins to be able to give hope for the expectations of nonLDII groups, at a minimum on demands that LDII be moderate and tolerant. This achievement is inseparable from the actors of Usman and Sunarto. In addition to LDII activists at the local level, nationally this organizational reform was supported by the headquarter of the LDII office which always made fundamental changes by cooperating with government and religious organizations, so as to be able to build LDII's branding as a more inclusive and open organization.

\section{BIBLIOGRAPHY}

Anonymous. (1971). Surat Keputusan Jaksa Agung RI No. Kep-089/DA/10/1971 tentang Pelarangan terhadap Aliran-Aliran Darul Hadits, Djamaah jang bersifat/ beradjaran serupa.

Anonymous. (1986). Kapitalisme dan Teori Sosial Modern : Suatu Analisis Terhadap Karya Tulis Marx, Durkheim dan Max Weber/Anthony Giddens. Jakarta: Penerbit Universitas Indonesia (UI-Press).

Anonymous. (1999). Potensi Wisata Kotamadya Kediri. Kediri.

Azra, A. (2000). Renaisance Islam Asia Tenggara. Bandung: Rosda.

Dove, M. R. (1988). Traditional Culture and Development in Contemporary Indonesia, dalam The Real and Imagined Role of Culture in Development, Case Studies from Indonesia. Honolulu.

Emerson, R. M. (1995). Writing Ethnographic Notes. In Ethnographic Fieldnotes. https://doi.org/10.1016/j.aprim.2016.06.011 
Fetterman, D. M. (2010). Ethnography: Step-by-Step. Sage. https:// doi.org/10.1002/1521-3773(20010316)40:6<9823::AID ANIE9823>3.3.CO;2-C

Giddens, A. (1984). The constitution of society: Outline of the theory of structuration. In The constitution of society: Outline of the theory of structuration. https://doi.org/10.1007/BF01173303

Giddens, A. (1990). Introduction. In The Consequences of Modernity. https:// doi.org/10.2307/591454

(2016). Modernity and self-identity. In Social Theory Re-Wired: New Connections to Classical and Contemporary Perspectives: Second Edition. https://doi.org/10.4324/9781315775357

Howell, J. D. (2005). Muslims, the new age and marginal religions in Indonesia: Changing meanings of religious pluralism. Social Compass. https:// doi.org/10.1177/0037768605058151

Morris, B. (2003). Antropologi Agama. Yogyakarta: AKA Group.

Spradley, J. P. (1979). The ethnographic interview. New York. https://doi. org/10.5615/neareastarch.77.3.0176

Thohir, M. (2009). Islam jamaah dan LDII; Doktrin Islam jamaah dan Sosialisasinya dalam Membentuk Kesalehan Warga LDII. Kediri.

Woodward, M. R. (2006). Islam Jawa. Yogyakarta: LKiS. 